\title{
Foreword
}

In my introduction to the first volume of Clark Kerr's memoirs-The Gold and the Blue, Academic Triumphs-I described the essentials of the remarkable academic and institutional advances of the University of California during the I950s and I960s, the period of Kerr's leadership as chancellor of the Berkeley campus and president of the university. I also attempted to assess his special role in the university's history during this period. My introduction paralleled the emphases made by Kerr himself in the first volume.

In introducing the second volume, I will touch on only three of the scores of possible dimensions the memoirs manifest-first, the nature of the conflict situation Kerr faced at the University of California in the I950s and I96os; second, Kerr in the midst of conflict; and third, Kerr the author of these volumes.

Before beginning, I might mention my own involvement in Berkeley politics during Kerr's years. I joined the sociology faculty in 1958 and spent my first six years in more or less private pursuit of my own academic career. In I964, still young and certainly unused to political hardball, I was engulfedlike most others-by the events of the Free Speech Movement. I was not an activist one way or the other in those months, but I was by a chance meeting drawn into the group that helped draft the statement that was telephoned to Kerr on October 2, 1964, and became the basis for the temporary settlement of the police car incident (pp. 195-200). In January 1965 Acting Chancellor Martin Meyerson asked me to be his main assistant for student political activities, probably because I had not been publicly identified with any faction (p. 259). In that position I was in a hot seat for eight months. For example, during the filthy speech movement, I was the point person working with the campus police, holding at bay Art Goldberg and a few other noisy activists, overseeing the student disciplinary process, and fielding (mainly hostile) phone calls from regents, the governor's office, and alumni. In 1966-68 I served as Chancellor Roger Heyns's assistant chancellor for educational development. In that position I was responsible for receiving and dealing with many controversial proposals to radicalize and otherwise alter the campus curriculum. In 1970 I was a member of Berkeley's Senate Policy Committee- the politi- 
cal arm of the senate that succeeded the Emergency Executive Committee of 1964-65. That spring witnessed the Kent State and Jackson State killings, and, closer to home, the "reconstitution" movement. I drafted the committee's official statement condemning the reconstitution movement. Kerr did not know me well during his years as chancellor and president, but in subsequent years we became and remain friends.

\section{Berkeley and Politics}

In establishing the University of California, the Organic Act of I868 tried to shield the university from "sectarian, political or partisan influence" (p. I23). Yet the rest of the world seems not to have heeded the directive. The whole of the university's history has been marked by political heat:

the political campaign by California agriculture and trade union interests in the late nineteenth century to make the university an "applied" institution the post-World War I red scare, which precipitated the university's adoption of required American history and American institutions courses

the left-wing political activism of the depression years, resulting in the adoption of the restrictive Rule 17

the efforts to impose a loyalty oath on faculty in the McCarthy years the Free Speech Movement, the antiwar movement, and racial advocacy in the r 960 s

the fight over divestment of university funds in South Africa in the I980s the regents' vote to prohibit racial and related categories as admissions criteria in 1995 and the subsequent passage of Proposition 209 by the voters of the state of California

Of course, by comparison with other parts of the world-Latin America and former Communist and socialist countries, for example-all American universities have been relatively free from political interventions. Nevertheless, the discrepancies between the state's original legislative intent and the historical reality are remarkable.

Why was the university, born free as it were, destined to be the arena of so much political controversy? I do not have the answer to this question, but several considerations can be ventured. First, the university has never itself been 
a seat of much power, but it has been a highly valued economic and cultural asset — perhaps even a sacred object—-for the aware and concerned citizens, including political leaders, of the state. Therefore, it has always been important for partisan citizens to imprint on the university, as prized object, their particular sectarian preferences and political positions. To do so is a symbolic way to endow their partisan and secular desires with officialness, legitimacy, and even sacredness by imposing them on the university's mission and activities.

A second consideration arises from the fact that the state, in mandating freedom from partisan and political influences, is in fact enunciating a two-way contractual understanding between the state and the university, though the terms of this contract usually remain implicit. That contract is, in essence, that in exchange for their freedom (including academic freedom), the various constituencies within the university-administration, faculty, staff, and students - will reciprocate by holding to standards of civility, dispassion, and political neutrality in carrying out the university's missions. These constituencies, however - particularly students and faculty — are in reality not apolitical. From time to time they engage in partisan activities, sometimes launching them from university campuses. Most often they do so in the belief that they are (and ought to be) acting with impunity, under the cloak of academic freedom. From the outside, however, their activity is regarded though not always articulated as a breach of the contract, and it invites political intervention. Taking these two considerations together, then, I suggest that the periodic politicization of the university rests on a combination of internal and external forces.

A third set of forces also works toward producing the frequent episodes of politicization experienced by all public institutions of higher education, and the University of California in particular. These have to do with the number and complexity of the political constituencies they encounter. In the first instance, a public university is a creature of the state, dependent on the state for its charter and much of its yearly financial sustenance. No state can expend such amounts of public funds without its legislative and executive branches taking a keen interest in how those funds are spent and how its university conducts its affairs. In California the Board of Regents is appointed by the incumbent governor, who usually appoints people from among his (never "her" in California up to this point) political supporters. This arrangement is probably a less political one than it is when regents (as trustees) are elected directly by the state's citizens, but it is political all the same. 
In addition, those who direct universities' affairs must continuously deal with a mass of other constituencies. The most immediate of these are faculty, students, staff, alumni, and the surrounding community (the "town" environment for the "gown"). University leaders quickly learn that these constituencies regard themselves as shareholders if not owners of the institution (Rosovsky 199I) and that leaders cannot endure long if one or more of them become seriously alienated from their otherwise beloved institution. Add to these constituencies those who have appeared more recently in universities' histories - federal and foundation granting agencies, federal and state environmental regulators, and an increasing number of social movements, of which the environmental movement, the women's movement, various racial and ethnic movements, and the animal rights movement are conspicuous examples.

Given this array of interested political constituencies, it is scarcely surprising that universities experience a great deal of political heat, and that their presidents and chancellors typically devote most of their time, energy, and anxieties to dealing with political pressures, political conflict, and crisis-management. The more eminent the university, the more it seems to be subject to politicization. I suppose that results from the fact that people care more about great and consequential institutions than they do about mediocre and less visible ones.

The two most fundamental political crises in the University of California's history were the loyalty oath controversy of I949-50 and the Free Speech Movement of 1964 followed by several years of antiwar protest. As a young faculty member, Kerr played an important conciliatory role in the former, a role that made him visible to those seeking university leaders in subsequent years. And as president of the university, he was the central actor in the turbulence of the I96os, though he "missed" the campus violence, the racial protests, and the People's Park episodes of 1968-69, which occurred after his dismissal as president in 1967.

Kerr covers the loyalty oath years and other political events in Political Turmoil but understandably directs his principal attention toward political conflict in the years of his university leadership. I will also concentrate on this period in this introduction. To the student of social movements-especially one who has had thirty-five years to think things over-the years between 1960 and I967 represent themselves, in almost textbook form, as a scenario for social revolution. I am not suggesting that the Free Speech Movement and its aftermath represent any kind of full-scale political revolution (even though a 
few striking parallels, such as the toppling of a chancellor, obviously come to mind). Some interesting analogues to a revolution, however, can be noted.

To be specific, the period between the late 1950 and 1967 witnessed three distinct concatenations of circumstances-occurring in sequence, one after the other-that go far in explaining the political dynamics of that decade:

a recipe for rising expectations and rising dissatisfaction

a recipe for revolutionary activity

a recipe for counterrevolutionary activity

Kerr lays out the essentials of these recipes, but not exactly in those terms.

Expectations and dissatisfaction rose in the six or seven years before 1964. They were fueled by one internal and one external change. This first is the series of liberalizations in the Berkeley campus political life engineered by Kerr himself. These included making military training in the campus ROTC program voluntary, establishing an "open forum" for political discussion, allowing Communists to speak on the campus, and prohibiting discrimination in campus fraternities and sororities. The political/psychological consequences of these relaxations were an atmosphere of greater freedom and higher hopes than was possible under the previous, more restricted years. (In this limited sense, Kerr can be regarded as one of the architects of his own revolution!) The external change was the heightening of political aspirations — especially among students and the young-occasioned mainly by the successes of the civil rights movement and the optimism engendered by the election of John F. Kennedy as president. Heightened hopes and idealism almost necessarily engender higher dissatisfactions because they raise the standards by which dissatisfaction is measured, thus making it more salient. Expressions of both the hopes and the dissatisfaction were evident in the increasing level of political protest on the Berkeley scene between 1960 and 1964.

A recipe for revolutionary activity was concocted in the months between September and December 1964. Its first ingredient was the abrogation of a valued political right - the use of a certain strip of land on the edge of the campus as a site for political advocacy and activity. Activists and others experienced this as an outrageous revocation of a legitimate entitlement. The second was the seemingly unjust punishment meted out to those who protested the revocation. The third was the campus administration's vacillation between harshness and faintheartedness in imposing that punishment-a vacillation occa- 
sioned by a divided university authority. ("Splintered" is more apt than "divided," given the splits within the campus administration, between campus administrators and the faculty, and between campus administrators and the president.) The fourth ingredient was the fashioning of a succinct, engaging, and fully legitimate slogan —Free Speech—by the movement's leaders, a slogan that accomplished a wonderful simplification of a complicated and entangled political and legal situation and provided an effective basis for political mobilization. The fifth ingredient was the appearance of a charismatic leader, in the person of Mario Savio, who possessed impressive political and oratorical skills. No revolutionary could hope for a more fortuitous mix of circumstances, and no political authority could imagine a more dreadful one.

Counterrevolution emerged in large part as an expectable consequence of the earlier phases. It was stimulated by a significant residue of anti-Communist sentiment in the state, inherited from the years of McCarthyism and the loyalty oath controversy and fueled continuously by Cold War anxieties. This sentiment carried with it both suspicion of university students and faculty and hostility to them, especially at a university like Berkeley with a long-established liberal/radical reputation. A second stimulus was the collapse of authority (the chaos of Chancellor Strong's response to the crisis and his departure in December 1964) that saddened and enraged many alumni and political leaders and became the focus for mobilizing all the law-and-order elements of the state. The counterrevolution unfolded in several ways. One manifestation was a savage yet pathetic attack on Kerr and others by former Chancellor Strong in letters published in the Oakland Tribune in March 1965, during the frenzy of the filthy speech movement. Another was a repeated assault on Kerr by the California State Senate Un-American Activities Committee, which, although discredited, took its toll. The most important manifestation, however, was the election of Ronald Reagan in 1966. One of his rallying cries during his first gubernatorial campaign was to "clean up the mess at Berkeley." After his election a group of right-inclined regents and the governor gained enough votes to fire Kerr in 1967.

Regarding the conflict of the I96os in the University of California as a whole, one might remark that that turbulent period was an instance of what some historians and other social scientists are now calling a cultural trauma (Caruth 1996; Neal 1998). Conspicuous examples of cultural traumas are the great regicides of history, our own country's Civil War, World War I, and the holocaust years in Nazi Germany. These events leave a scar on the affected nations 
and populations. They are always loaded with strong, mostly negative effect, but sometimes with feelings of nostalgia and heroism as well. Cultural traumas have a certain indelibility. They are imprinted on the memories of those affected and seemingly cannot be eradicated. They are forever being remembered and reremembered and are never settled. A feeling is often generated that the affected nation or people will "never be the same" after the trauma. Cultural traumas also become the object of both denial and compulsive remembering through rituals and memorials. Furthermore, new events and situations that arise afterward are compulsively experienced, interpreted in the context of the historical trauma. They are objects of collective brooding, characterized by a lasting search for both who was victimized and who was to blame. Collective memories about cultural traumas also produce contestations. Interested groups insist that there are correct and incorrect ways to remember cultural traumas and conflict, and group polarization over how to remember persists for decades afterward.

It would be foolish for me to suggest that the convulsions of the I96os in California higher education are even remotely comparable in scope and effect with the cataclysmic traumas I mentioned. They were, in the end, localized and did not fundamentally challenge the political and cultural life of a whole society. Most people in the generations since the r96os do not remember the relevant events at all, and those who become familiar with them are likely to wonder what all the fighting was about. For those who experienced them, however-members of the "movement," involved faculty, involved administrators, political figures - and for historians who immerse themselves in the events, how to interpret and how to remember still evoke high feeling and disagreement. Even in the I990s, efforts to memorialize the Free Speech Movement on the Berkeley campus precipitated a minor political confrontation. There is also a general feeling that, whatever the 1960s were, they are an indelible aspect of the university's history and that, for better or for worse, the university will never be the same because of having experienced them.

In the light of these observations, I may suggest one way in which Kerr's memoirs will be received. In them he gives us his own story of himself and his historical circumstances. It is certainly a service to the world that he has done so, because no one else could offer his perspective and these accounts. He acknowledges that there will be other accounts, and many of them will be counteraccounts developed in response to his. Any era that is simultaneously as dynamic, as glorious, as conflict-ridden, and as traumatic as the 1950s and 
I960s were will have many rememberers. Moreover, their diverse memories are matters of contestation. In fact, the memories of such eras constitute not only a microcosm of different perspectives embraced at the time the events occurred, but also a reflection of how subsequent generations want to remember them. Because Kerr was at the center of the turmoil, his own accounts and memories assume a valence that is all the greater, and his memories will be a special object of interest for all other rememberers, both sympathetic and unsympathetic.

\section{Kerr the Leader and Kerr in Conflict}

In the introduction to the first volume, I made an effort to identify the combination of personal characteristics that made Kerr such an effective institutional leader in the years of the University of California's spectacular growth in size and quality in the I950s and 1960s. These were:

- his ability always to grasp the big picture, no matter what issue he was pursuing and no matter how intimately involved he was in that issue. That ability certainly appears in the pages of his memoirs. Whenever Kerr casts his analytic net and lists the six (or five, or eight) historical trends or forces at work in a given situation, we can rest assured that his diagnosis has nailed down the main ones and that other factors are secondary. Kerr's talent for grasping the big picture served him well in comprehending the complexity of higher education and engineering change on many fronts at once.

- his ability to translate his grasp of the big picture into a vision. Most scholars cannot or do not take this step. Kerr was able to conceive-not always in a completely conscious way, no doubt - a view of the future and the general directions that had to be followed to move toward that vision.

- his ability to ground understanding and vision in the realities of social, political, and economic life. He combined pragmatism with his idealism, and he could discern, in concrete ways, organizational and structural scenarios necessary to realize ambitious goals. He also understood the fundamental messiness of institutions - their imperfections as well as the nonrationalities and irrationalities of those who inhabit them-despite his unwavering, self-professed philosophy of rational optimism and trust in others.

- an exceptional power to persuade and influence, augmented by his open, modest personal style, which gave no hint of calculation or manipulation. His abil- 
ity to influence was a great asset for him in the world of academic administrators and faculty, where consensus building through persuasion-not the straightforward exercise of power and authority-is the name of the institutional game.

- a unique dedication, energy, and doggedness. These characteristics were what made Kerr into a determined fighter for his goals, even though he always fought in a nonfighting manner.

This mix of qualities, matched with the extraordinary historical opportunities in postwar California, assured Kerr a unique leadership position and helped the university evolve-in the complex, multifaceted way that it did-into the institution it became.

In these memoirs we also see the importance of these personal characteristics in the way Kerr managed conflict. In situation after situation we observe how he brought all interested parties on board in advance of important and potentially conflict-laden decisions or actions. In at least one critical incidentthe defusing of the "police car incident" in October 1964-his negotiating powers won the day, though the resulting agreement was transient. We also perceive his deft management of regental dynamics, even in times of high emotion and conflict. In a word, Kerr's personal qualities provide much of the reason why he survived as long as he did in the conflict-torn years of his leadership.

At the same time, it is clear that in those years conflict evolved to such a point that his substantial gifts of historical understanding, vision, practical wisdom, and consensus building could not prevail. These qualities become less effective, even reach their limits, when they encounter the dynamics of revolution and counterrevolution. Kerr discovered painfully, in dealing with both the protesting left and the counterreactive right, that the last thing that either wanted was to compromise and make peace. These were years of ideological confrontation, not pursuit of practical interests. The aims were to score victories and to discredit and ultimately destroy enemies, not to gain what one could and settle for less.

Furthermore, the sheer power of the forces with which Kerr had to contend signaled that they were, in the last analysis, beyond his control. He was dealing on his left with a set of social movements that, during their height and before they spent themselves, were extraordinarily potent. He was dealing on his right with an equally committed set of ideological groups, more powerful than the left because they emanated from sources- the regents and the state 
of California - that held power over Kerr's career. In the end they ended that phase of his career, thus reminding us that although exceptional persons may shape history in decisive ways, they are never immune to the perils lurking in the very history they are shaping.

\section{Kerr the Author}

Those who read these memoirs will notice that Kerr has a distinct expository style. He speaks in shortish, direct, declarative sentences. The style is almost telegraphic at times. Readers should not be misled by his style, which is deceptive in its simplicity. It should not obscure either the depth or subtlety of his grasp of his times or the profundity of his analyses and interpretations. Kerr the scholar is always present in these pages, and scholars will return to them repeatedly in the future, whether to learn from them or to contest them.

One of the most striking features of Kerr's story is his power of objectification. By this I mean his ability to step back from the events and situations in which he was a principal—and often controversial—actor and to describe and interpret them with a remove and dispassion that are almost incredible. This power permitted Kerr to develop, for example, a balanced and believable account of his greatest institutional lament- the failure of the Santa Cruz campus to live up to its promise and design. It also permitted him to develop objective accounts of the great conflicts by which he was engulfed.

To be sure, an elapse of time does give one the power to distance oneself from events. Nevertheless, we must wonder how many institutional leaders, when in the trenches of social change-many aspects of which they themselves are engineering — can maintain the kind of distance we observe in Kerr's accounts? Perhaps more aptly, we must ask how many people who have been severely scapegoated — as Kerr was continually, from both sides_can produce an intelligible account of the causes and dynamics of that scapegoating process, even with the passage of time? In reading these memoirs in toto before writing this introduction, I found this aspect of Kerr's mind and style to be the most intriguing.

One of the by-products of the capacity for objectification is self-objectification - the power to develop a sense of self-criticism. In many places in his memoirs Kerr grades himself harshly and frankly acknowledges grave mistakes that had serious negative consequences. At the same time, he sometimes criticizes the mistakes, unguided or misguided behavior, and wrongdoings of 
others-Robert Gordon Sproul, James Corley, Franklin Murphy, the radical left, the Reagan right - though he is careful to balance these criticisms with positive assessments, and he scrupulously avoids ad hominem attacks. Probably no single interested reader of these memoirs will agree completely with Kerr's balance of identifying problems and assigning responsibility. But to find such a balance in any person's memoirs is rare.

\section{A Note in Conclusion}

In these memoirs we find both vintage Clark Kerr and a great deal of what we have not seen before. The vintage Kerr is the social scientist, the analyst, the comprehender of social change and social conflict, and the master interpreter of them. What is new is of a more personal nature. We learn much about the parts of his background that are important to him, his working philosophy, and his personal assessment of and reactions to many who acted with him on the same stage during his eventful career. In addition, we are able to see coming through the down-to-earth, unassuming prose the deeper feelings as wellhis hopes and ambitions, his pride in things accomplished, his disappointments, his nostalgia, and his regrets.

Neil J. Smelser

University Professor of Sociology, Emeritus University of California

\section{REFERENCES TO THE FOREWORD}

Caruth, Cathy. 1996. Unclaimed Experience: Trauma, Narrative, and History. Baltimore: The Johns Hopkins University Press.

Neal, Arthur G. 1998. National Trauma and Collective Memory: Major Events in the American Century. Armonk, N.Y.: M. E. Sharpe.

Rosovsky, Henry. 1991. The University: An Owner's Manual. New York: W. W. Norton. 
This page intentionally left blank 